\title{
Strategic Management in Developing Natural Tourism
}

\author{
Tabitha R. Matana, Gitit I.P. Wacana \\ Universitas Sintuwu Maroso Poso \\ Indonesia \\ gititwacana@gmail.com
}

\begin{abstract}
This study aims to explore and identify the potential for tourism in the Valley Be'hoa for tourism development in the district of Poso as a source of foreign exchange. The method used is qualitative explorative. Data are analyzed based on Milles and Huberman analytical concept. The results of the study can be summarized as follows: 1) Valley Be'hoa has unique tourism potential, both from the aspect of nature, local culture, and cultural heritage sites Pokekea megalith region, Be'hoa valley tourism potential should be developed under some strategies that can be a reference in planning the development of tourism, which are: 1) To have high competitiveness of tourism products must have an icon Be'hoa valley travel as a superior product "era megalith culture village" .2) Improve and enhance the quality of accessibility to the attractions. 3) Establish a fixed agenda for the feast of arts and culture in the valley Be'hoa, integrated with travel agenda "Lore Brothers". 4) Intertwined interconnection between stakeholders, both public and private. 5) Develop an integrated package with a cross-regional travel.
\end{abstract}

Keyword: strategic management, megalith tourism, interconnection.

\section{INTRODUCTION}

Security issues did not deter the public activities of Poso in developing region after ten years the conflict of Poso in improving itself to keep pace. Economic growth is the development of activities in the economy that led to the goods and services produced in the community grows so will increase the prosperity of society [1]. Moreover, economic growth is defined as the increase in GDP / GNP regardless of whether the increase is larger or smaller than the population rate growth, and whether there is a change of economic structure or not [2]. The average of economic growth in Poso District from 2003 to 2012 is $6.39 \%$, which is categorize high, but when compared with other regions it is still less competitive. Tourism sector is less developed in Poso district, it is expressed through original local revenue data from the tourism sector
Poso Regency GRDP has increased, in 2012 at the crutch by the three main sectors, namely agriculture $44.43 \%$, trade, hotels, restaurants $14.94 \%$, and the services sector $10.98 \%$. Poso district, in the spirit of regional autonomy, the government should explore the potential sources of revenue, one of which is the tourism sector. One of the tourism potential by Poso district in the district of Central Lore (Doda) is very diverse, but the awareness of the community and the district governments is minimal on the wealth of tourism potential, appear on accessibility to tourist sites not maintained [3]. This is in line with the results of research conducted by Pelombe which states that development of tourism facilities in the district of Poso still very minimal, with different potentials, needs development and better handling [4]. Likewise, another research states that tourism potential in the area West Lore should be developed not only by nature, but also cultural tourism [5].

In 2003 the research ministries of culture and tourism of Indonesia stated that public participation in the development of a tourist destination is still low. One contributing factor is the absence of clear and detailed provisions on community involvement in the development of tourist destinations (DTW) [6]. Community involvement in tourism development is beginning from the planning, implementation, supervision, so that the sustainability of tourism development can be guaranteed, because the carrying capacity of the public will minimize negative impacts. Statistically, tourist arrival to Central Sulawesi in 2012 is only 9255 people. This figure is up slightly from the previous year, 7163 people. Travellers with the main destinations of Lake Poso are about 1,000 people. There are many varieties of tourism potential in the area of Lore brothers that can be developed to increase community's income and as a source of revenue for Poso district.

\section{LITERATURE REVIEW}

\section{A. Economic growth}

The law on regional autonomy has given greater authority to local governments to administer and manage the development of their respective regions. With decentralization Poso district needs to take part in various aspects of economic potential possessed in order to increase economic growth and development of the development based on the empowerment of human resources. In Poso district, there are 19 districts with economic growth rates varied among districts. 
Economic growth is the development of activities in the economy that lead to the goods and services produced in the community grows so will increase the prosperity of the community. Economic growth is defined as the increase in GDP / GNP regardless of whether the increase is larger or smaller than the population growth rate, and whether there is a change of economic structure or not. Average economic growth in Poso District from 2003 to 2012 is amounted to $6.39 \%$, which is quite high, but when compared with other areas, it is still unable to compete.

Economic growth is influenced by several factors: (1) the growth of population and labor force, (2) the accumulation of capital, (3) the advance of technology [7]. There are several tools to measure economic growth, namely: Brutu Domestic Product and Gross Domestic Product Per Capita. It is more specifically said that economic development in other words no longer worships GNP as development targets, but more focused on the quality of the development process [8].

Development of the region held in Indonesia at least includes three levels, namely at the level of the micro, meso and macro. At the micro level aims to identify urgent needs and meet the basic needs of the community, help the region in order to achieve economic independence and improve competitiveness, as well as encouraging the development potential of the region to be able in exporting industrial or agricultural, to support the national economy.

The structure and condition of the region for each region is different. This has implications for economic policy formulation and development planning [10]. Poso District continues to experience growth in public administration area since 1999 with the expansion of Tojo Una-Una, Morowali, and North Morowali. Poso District itself has the creation of districts into 19 sub-districts. Each of the districts has the economic potential to be developed with a good net work across regions.

The principal issues in regional development is located in its emphasis on development policies based on the uniqueness of the area in question by using the potential of human resources, institutional, and physical resources locally (local). Development policies need to plan so that everything that comes from the area in the development process to create new employment opportunities and stimulate increased economic activity. Data Gross Regional Domestic Product is one very important indicator in the planning and evaluation of development. The population of the district of Poso in 2012 reached 226.389 people. This amount is the result of population projections based on the results of the Population Census (SP) in 2010. The number of the male population reached 117.667 inhabitants, while the number of females 108.722 inhabitants. If compared to the year 2011 the population of the district of Poso growing increase of 6.23 percent, or 13.293 people. The rapid population growth shows the increasing of Poso district economic growth. Along with population growth, the population density is also increased. The population density was recorded 26 inhabitants $/ \mathrm{km}^{2}$, with an area of $8712.25 \mathrm{~km}^{2}$ Poso district. Poso Kota District is an area that has the densest population is 1.712 people $/ \mathrm{km}^{2}$ and an area of $12.8 \mathrm{~km}^{2}$, while the District of Central Lore terjarang have the population about 4 people $/ \mathrm{km}^{2}$ with an area of $976,37 \mathrm{~km}^{2}$. people / $\mathrm{Km}^{2}$ with the total area of $976,37 \mathrm{~km}^{2}$. (BPS Poso, 2012).

Efforts to improve the region's economic growth, it is necessary to take into account local characteristics (specialization, diversity and competition) and their investments. Differences in regional conditions have implications for the development that is applied to the region. If you will develop an area, then it needs to be adapted to the conditions (problems, needs and potential) of the region. Therefore, it is necessary to do an in-depth research on the condition of each region that is useful as a reference in development planning in the region. The development of economic activity in a region which increased the prosperity of the community planning is necessary in accordance with the conditions of each area. The development of economic activity Poso district can be assessed in several sectors, one of which is the tourism sector. Strategic planning is based on the tourism potential data $\mathrm{w}$ isata and specific conditions of an area to be able to become a tourist destination. Classification of tourist destinations (Destinations) based on several factors: 1) nature; 2) culture; 3) traffic / accessibility; 4) economic activities; 5) political activities / central government [11].

\section{B. Growth Centres (Growth Poles)}

Perroux said growth does not appear in different regions in the same time. Growth occurs only in some places referred to as the center of growth with different intensities. Growth center is basically a collection of economic activity around the aircraft industry. Growth center contains two aspects: the functional and geographical aspects. The functional aspect is kelo Mpok concentration of effort, the geographical aspects of a site that has many amenities and services to become a center of attraction [12].

It is found that the concentration of manufacturing industries in Java Indonesia gathered at a concentration that constitute the two poles (bipolar pattern) [Kuncoro]. Patterns concentrations found by Kuncoro is on the western tip of Java island which includes Jakarta, Bogor, Tangerang, Bekasi and Bandung, while on the eastern tip of Java island centered in the area of Surabaya. The concept of growth centers can be used in the development of regional economic activity tourism sector. Growth center is embracing the concept of concentration and decentralization simultaneously. In determining the location of the center of growth to note the various advantages possessed by the region concerned, among other things: 1) the road network, telecommunications covering the entire region,; 2) the potential economic potential to be developed; 3) the relationship between the input and output of each industry; 4) determine the types of facilities and infrastructure for the development of growth centers; 5) forming an organization that will manage and coordinate the growth center.

\section{Tourism concept}

Tourism means traveling done by someone, who travels for pleasure temporarily not to settle or work. In tourism activities there are three elements in it that: the movement of travelers, community activities that facilitate the movement of travelers, 
and the implications of the movement of travelers and community activities that facilitate the wider society [14].

Tourism as an economic activity must be viewed from two sides namely, the demand side and the supply side, success in the development of tourism sector in a region highly dependent on the ability of planners to integrate both sides are balanced in a tourism development plan [15]. Importance of Tourism in developing countries because tourism is the principle of "export" (foreign exchange earner) for $83 \%$ of the developing countries, and leading export for $1 / 3$ of the poorest countries. For the 40 poorest countries in the world, tourism is the second most important source of foreign exchange, after oil. Tourism in developing countries increased by $9.5 \%$ per year compared with 4.6\% worldwide. (Global ecotourism, 2013). It is demonstrated empirically that ecotourism plays a role in the conservation of four indicators, namely the financing of conservation, conservation education, conservation ethic, and resource conservation [16]. As in the case of poverty issues, ecotourism contribute to the improvement of local people's income level, an increasing number of people who work, infrastructure improvements, and local participation.

\section{METHODOLOGY}

In analyzing the problems in this study, the method used is qualitative descriptive by using purposive and snowball sampling technique. Data are analyzed based on Miles and Huberman data analysis model, which includes data reduction, data display, and drawing conclusion/verification.

\section{A. Techniques of collecting data by means of triangulation, namely:}

- Interview: semi-structured interviews; using a structured interview list and is open to explore in depth information.

- Documentation; documentation originating from the subject, informants, as well as documents from the village office, offices of tourism, and related agencies

- Observation: Observation of Attraction and community activities.

\section{B. Area of Research: Regional Lore brothers consisted of 6 districts}

\section{Analysis of Data Analysis of the data used in this study are:}

- Analysis of qualitative descriptive

- SWOT Analysis

\section{RESULTS AND DISCUSSION}

Research is beginning to be implemented by taking secondary data on local revenue offices and departments of tourism, then proceed to take the data in the district of Central Lore. Districts of Central Lore is a division of North Lore districts. Vast districts of Central Lore is $977,25 \mathrm{~km}^{2}$ consisting of eight villages, which are Doda, Bariri, Baleura, Hanggira, Lempe, Torire, Rompo, Katu. Based on BPS data in 2009 the population is about 4296 people, consisting of 2202 men and 2094 women. Livelihoods is mostly in the agricultural sector; food crops (rice), gardening (cocoa), rising pigs, and chicken.

Subdistrict Central Lore is known in general with Beshoa valley, but for the local community that has meaning to mention Be'Hoa splitting wood with an ax. Central Lore is the result of the division of the sub-district of North Lore. Implementation of the division September 29, 2001 with a capital district in the village of Doda who have public facilities such as health centers, elementary and junior high school, the office of the police sector, standard inn.

\section{Tourism potential}

People in the Be'hoa Valley are famous with hospitality in receiving migrants / guest. The administration of Be'hoa valley is at the Central Lore District consisting of eight villages with almost every village has tourism potential that should be developed. Various potential aspects that should be developed are aspect of natural landscapes, protected areas, cultural, and objects of cultural heritage megaliths of the past. Exploration results and the identification of the potential of tourism in the valley Behoa are as follows:

\section{1) Natural Attractions.}

Natural tourism potential owned by Behoa valley diverse consisting of a rare form of Anoa Fauna in the vast grasslands field called Tadulako, Kana, and Mangora paddock. The natural conditions is still be found in every village. Waterfalls located in the village of Doda, sulfur hot spring in the village Lempe, Rompoh village, and the village of Katu. There is a Lake +8 Ha located in Torire village is used for fishing, its location via Laeriang river, but access to that location is rather difficult. In the village, there is a statue Torire megaliths at the center of the desert road leading to the lake. Doda village directly adjacent to the West Lore District is surrounded by protected forest that has a wealth of flora and fauna.

\section{2) Cultural Attractions}

Cultural tourism potential possessed by the people of the Be'hoa valley is similar and likely the same as the people of the Bada valley in its form of dance called Raigo, Dulua, Envy, as well as bamboo music in every village. Tulumpe is a traditional musical instrument which is also made from bamboo. Crafts such as wicker is made from grass (rushes) are still there. Crafts such as carvings are poorly developed, only one parent in the village of Doda did. Ma'paruja tradition had been left to be replaced with modern tools, only Hanggira village still do it. Ma'paruja is a tradition that prepare paddy field trampled by a group of buffaloes instead of plowing, which is accompanied by the sound of screaming typical of the men on the edge of rice fields. Be'hoa Valley community has a traditional house called Tambi which has the same characteristics with custom home communities in the Bada valley. Tambi can be found in good condition in the village of Katu, but access to the location of the custom house a little difficult when the rainy season. 
Lempe village is an old village in the Be'hoa valley, there is an old village surrounded by ancient ramparts, and there is also an old graveyard alleged ancestral graves Be'hoa people with a length of 3 meters. Ancient fortress and old graves are at the location of protected forest. Local communities hope that the old village location back into their right to manage as cultural heritage village. Be'hoa valley has potential archaeological sites that are at the Hanggira village (Pokekea), Doda village (largest Tadulako), Bariri village (largest desert Masora), Lempe village (largest Taipa field), and Hanggira village (Entovera largest and Hadoa field). A village with the findings in the form of a stone statue, stone mortars, Kalamba, dakon stones, flat stones, etc. In the village, there are also Rompo megalith sites Watumega (distance $+1 \mathrm{~km}$ ) and Watumeboku (distance $+1.5 \mathrm{Km}$ ) from the village. Archaeological sites become an attractive and potential tourism destination, but should be well-governed. Structuring the archaeological site as one of the attractions need strict regulation and integrated from the various parties concerned in view of archaeological sites including objects of cultural heritage, based on Law No. 5 of 1992 on objects of cultural heritage.

\section{3) Accommodation}

Accommodations Attraction supporting tourism object is lodging or home stay located in the district capital as much as 2 pieces that are Grace inn and Rezky inn. Those two inns have standard facilities and reasonably priced. The food choice is limited in which it is only prepared by the inn, there are no food stalls.

\section{4) Access and Transport}

The distance between one villages to another is quite far, affordable by motorcycles and cars. Katu village is rather inaccessible during the rainy season because roads have not been paved. Main road facility into the Beho'a valley is more accessible that is from the north, but with the condition of the road and some point to experience landslides. Wuasa journey is taken from the capital district of North Lore to Doda approximately 2 hours by car.

\section{5) Travel Information}

Local tour guide and translator have not been existed yet, but so is the information of the performing arts. There are still no brochures, maps and advanced communication facilities. Information for the attractions in the Valley Behoa official has not existed yet.

\section{6) Health Services and Tourism Police}

There in still no health-care facilities at the village, there is only one health center. The security police there, but that specifically address the issue of travel does not exist.

\section{7) Facilities Shopping}

Shopping facilities in the form of Art Shop which sells handicrafts sustain local attractions yet.

\section{8) Human Resources}

Human resources in the Be'hoa valley are potential enough, it's just not empowered to maximum, but also it has a desire to work and work in the travel sector. Starting a business commercially is still confused, and still expects help from the government.

\section{THE ANALYSIS SWOT DEVELOPMENT OF TOURISM POTENTIAL.}

Based on the results of the identification of the tourism potential of the Be'hoa valley on internal and external factors, it can be arranged alternative tourism development in the Be'hoa valley using SWOT analysis (Strenghts, Weaknesses, Opportunities, Threats). The development strategies that can be generated from SWOT analysis (see Table 1). 


\begin{tabular}{|c|c|c|}
\hline & (Strength) & (Weakness) \\
\hline Eksternal & $\begin{array}{l}\text { 1. The diversity of Flora and Fauna } \\
\text { 2. Natural view is still beautiful and natural. } \\
\text { 3. Hospitable community } \\
\text { 4. Ma'paruja unique culture and other culture } \\
\text { 5. There are large tracts of land for tourist } \\
\text { development } \\
\text { 6. Have some locations of archeological sites. } \\
\text { 7. Art contest activity among villages. }\end{array}$ & $\begin{array}{l}\text { 1. Accomodation facilities are limited and inadequate } \\
\text { 2. Lack of knowledge and a good understanding of the } \\
\text { public about the handling of archaelogocal sites as } \\
\text { objects of cultural heritage (BCB) } \\
\text { 3. Limitation of human resources in the field of Tourism. } \\
\text { 4. Lack of supporting facilities such as artshop and } \\
\text { tourist information. } \\
\text { 5. Governance attractions are inadequate. } \\
\text { 6. Accessibility is still very low from Poso and Palu. } \\
\text { 7. The lack of coordination among related agencies. } \\
\text { 8. The lack of human resources working in the tourism } \\
\text { sector. }\end{array}$ \\
\hline (Opportunities) & Strategy I (S/O) & Strategy III (W/O) \\
\hline $\begin{array}{l}\text { 1. The uniqueness of the natural potential of } \\
\text { already known foreign owned. } \\
\text { 2. Exploiting the potential of natural, carufully } \\
\text { planned, integrated with relevant agencies } \\
\text { stakeholders. } \\
\text { 3. Interest of foreign and domestice travelers to }\end{array}$ & $\begin{array}{l}\text { 1. Product development and travel bio or } \\
\text { cultural megalith tourism } \\
\text { 2. Development of various tourism products, } \\
\text { such as fishing and camping. } \\
\text { 3. Development of a cultural village area }\end{array}$ & $\begin{array}{l}\text { 1. Improving the quality of tourist attraction with } \\
\text { improved facilities and infrasturcture that support } \\
\text { the attraction. } \\
\text { 2. Development of an integrated tourist packages } \\
\text { associated with the intensity of cross-regional }\end{array}$ \\
\hline
\end{tabular}




\begin{tabular}{|c|c|c|}
\hline \multicolumn{3}{|c|}{ Advances in Economics, Business and Management Research, volume 15} \\
\hline$\Delta$ the attracpRESSS & & network. \\
\hline 4. Improved quality of road. & & $\begin{array}{l}\text { 3. Prepare the agenda of the annual celebration of art } \\
\text { and culture. }\end{array}$ \\
\hline $\begin{array}{l}\text { to various locations attraction } \\
\text { 6. Interest visiting foreign and domestic scientist } \\
\text { to conduct research }\end{array}$ & & $\begin{array}{l}\text { 4. Regulations are directly realted to the } \\
\text { development of tourism potential has not been } \\
\text { adequated.. }\end{array}$ \\
\hline $\begin{array}{l}\text { 7. Some investors are interested in the } \\
\text { development of Beho'a valley }\end{array}$ & & $\begin{array}{l}\text { 5. Development of tourist information with minimal } \\
\text { prepare personnel proficient in English. }\end{array}$ \\
\hline & & $\begin{array}{l}\text { 6. Develop a standard tourist information pack. } \\
\text { Regarding the tourism product offered by Beho'a } \\
\text { valley. }\end{array}$ \\
\hline Threats & Strategy II (S/T) & Strategy IV (W/T) \\
\hline $\begin{array}{l}\text { 1. Attraction Marketing depends on tourism } \\
\text { products from other regions, especially from } \\
\text { South Sulawesi. } \\
\text { 2. Changes in the socio-cultural } \\
\text { 3. Limited access of roads and communications.. } \\
\text { 4. Travel icons undeveloped, so that the } \\
\text { competitiveness of tourism products is lower } \\
\text { against other regional tourism product.. }\end{array}$ & $\begin{array}{l}\text { 1. Develop a leading tourism product design to } \\
\text { marketing strategy. } \\
\text { 2. The development of supporting programs } \\
\text { which are interrelated: roads, } \\
\text { communication networks.. } \\
\text { 3. Establish travel icons as products that have } \\
\text { high competitiveness. }\end{array}$ & $\begin{array}{l}\text { 1. Develop the concept of the rule in developing the } \\
\text { tourism potential in favor of legislation the } \\
\text { protection of cultural heritage objects.. } \\
\text { 2. Preparing human resources. } \\
\text { 3. Building interconnections between related sectors } \\
\text { both public and private. }\end{array}$ \\
\hline
\end{tabular}




\section{CONCLUSIONS}

Based on the analysis, it can be concluded that the development of natural tourism in the Be'hoa valley with four pillars, namely:

- Government Regulation

- Management of Development of Infrastructures

- Management Marketing and Promotion

- The management and the role of the community.

With these four pillars will sustain travel product Be'hoa valley, so the high competitiveness of tourism products have travel icon as a superior product.

- Improve and enhance the quality of accessibility to the tourism objects.

- Establish a fixed agenda for the feast of arts and culture in the Be'hoa valley, integrated with travel agenda at "Lore Brothers".

- Intertwined interconnection between stakeholders, both public and private.

- Develop an integrated package with a cross-regional travel.

\section{REFERENCES}

[1] Sukirno, S. 1994. Ekonomi Pembangunan : Proses, Masalah, dan dasar Kebijakan. Rajagrafindo. Jakarta

[2] Arsyad, Lincolin. 1999. Pengantar Perencanaan Pembangunan Ekonomi Daerah. Penerbit BPFE. Yogyakarta.

[3] Matana, Tabita, R. 2010. Potensi Wisata Budaya Kabupaten Poso. Jurnal Kepariwisataan. Vol. 2 No.02 : 133-144.

[4] Pelombe, Dante. 2011. Analisis Potensi Wisata di Kabupaten Poso. UNSIMAR.Skripsi. Poso.

[5] Kaitu, I. 2008. Fenomena Sosial Ekonomi Pengrajin Kain Fuya Desa Tuare Kecamatan Lore Barat Kabupaten Poso. UNSIMAR. Skripsi.Poso

[6] Suranti, S. (2005). http://www.kompas.com. [28 februari 2009]

[7] Todaro, M dan Smith, S.C. ( 2006) Pembangunan Ekonomi. Erlangga. Jakarta

[8] Mier, Gerald M. 1989. Leading Issues Economic Development, Oxford University Press. New York.

[9] Soedjito, Bambang Bintoro. 1997. "Strategi Pengembangan Kawasan Timur Indonesia" dalam Bunga Rampai Perencanaan Pembangunan Di Indonesia. PT Gramedia. Jakarta

[10] Sjafrizal. 2012. Ekonomi Wilayah dan Perkotaan. RajaGrafindo Persada. Jakarta.

[11] Pendit, Nyoman,S. 2006. Ilmu Pariwisata.Pradnya Paramita. Jakarta

[12] Tarigan,R. (2012) Ekonomi Regional. Teori dan Aplikasi. Bumi Aksara. Jakarta

[13] Kuncoro, M. 2002. Analisis Spasial dan Regional Studi Aglomerasi \& Kluster Industri Indonesia. Cetakan Pertama, Penerbit UPP AMP YKPN, Yogyakarta.

[14] Pitana, I Gde.dan Diarta I Ketut. 2009. Pengantar Ilmu Pariwisata. Andi. Yogyakarta.

[15] Gunn. 2008. www.budpar.go.id. [11 Oktober 2008]

[16] Agrawal A, Redford K. 2006. Poverty, Development and Biodiversity Conservation: Shooting in the Dark. WCS Working Paper Nomor 26. New York: Wildlife Conservation Society. http://www.wcs.org/science [1 Juli 2009]. 